\title{
Tindak Kekerasan Pada Tokoh Perempuan Dalam Novel Perempuan Kembang Jepun Karya Lan Fang dan Novel Kembang Jepun Karya Remy Sylado
}

\author{
Violence Against female Characters in Lang Fang's Novel Kembang Jepun and Remy \\ Sylado's Kembang Jepun
}

\author{
Siti Restu Rahayu*1, Aldi Alfaruk ${ }^{2}$, Novi Diah Haryanti ${ }^{3}$ \\ ${ }^{1,2,3}$ Program Studi Pendidikan Bahasa dan Sastra Indonesia, UIN SYarif Hidayatullah Jakarta, \\ Indonesia \\ e-mail:*1sitirestu16@mhs.uinjkt.ac.id, ${ }^{2}$ adi.alfaruk16@mhs.uinjkt.ac.id, ${ }^{3}$ novi.diah@uinjkt.ac.id
}

\begin{abstract}
ABSTRAK
Novel Perempuan Kembang Jepun karya Lan Fang dan novel Kembang Jepun karya Remy Sylado keduanya memiliki kemiripan yakni terjadinya kekerasan terhadap perempuan pada masa sebelum kemerdekaan dan pascakemerdekaan. Tujuan penelitian ini adalah menganalisis tindak kekeran terhadap tokoh perempuan dalam kedua novel tersebut dengan menggunakan metode sastra bandingan dan mempertalikannya dengan fenomena kekerasan perempuan saat ini berdasarkan Catahu Komnas Perempuan 2020. Kekerasan-kekerasan pada kedua novel ini terjadi di dalam dua ranah, yaitu ranah privat/personal dan ranah publik/komunitas. Pada novel Kembang Jepun kekerasan lebih ditonjolkan di ranah publik berupa kekerasan fisik, psikologis, dan seksual. Sedangkan pada novel Perempuan Kembang Jepun kekerasan ditonjolkan dari ranah privat/personal yaitu dalam hubungan rumah tangga yang dijalani pemeran utama berupa kekerasan fisik, psikis, seksual, dan ekonomi.
\end{abstract}

Kata kunci: Feminisme, Kekerasan, Kembang Jepun, Perempuan Kembang Jepun, Sastra Bandingan.

\begin{abstract}
Perempuan Kembang Jepun novel written by Lan Fang and Kembang Jepun novel written by Remy Sylado have a similarity which is telling the reader about abusing on woman in pre-independence and pascaindependence. Both of novels were examined by comparative literature and feminism theory. The object of this research is analyzing the abusing on woman in both novel and associating them with woman abusive phenomenon nowadays based on Catahu Komnas Perempuan 2020. The violence in these novel were happened spesifically in two aspects, those are private and public. Kembang Jepun novel concerns on public aspect, such as physical abuse, psychological abuse, and sexual abuse. On the other hand, Perempuan Kembang Jepun novel concerns on privat aspect spesifically in domestic life as physical abuse, psychological abuse, sexual abus, and also economical abuse.

Keyword: Abuse, violence, Comparative Literature, Feminism, Kembang Jepun, Perempuan Kembang Jepun
\end{abstract}

\section{PENDAHULUAN}

Indonesia merupakan negara yang melindungi setiap warga negaranya, hal tersebut sudah diatur dalam pasal-pasal yang sesuai dengan konstitusional. Pasal mengenai perlindungan terhadap kekerasan perempuan pun sudah tertuang dalam undang-undang yang sesuai dengan konstitusional yang berlaku. Komnas perempuan mencatat ada empat puluh hak konstitusional yang terdiri dari 14 rumpun di antaranya tertuang dalam pasal 28G, pasal 28G (2), pasal 281 (2), dan pasal 28H (2)[1]. Dari beberapa pasal yang sudah disebutkan tersebut semuanya membahas mengenai perlindungan atas hak-hak yang harus didapatkan oleh perempuan terutama hak atas kekerasan yang terjadi terhadap perempuan. 
Peneliti [2] membagi tindak kekerasan menjadi empat bentuk yaitu kekerasan fisik, seksual, psikologis, dan deprivasi. Bentuk kekerasan fisik dalam hal ini berupa kekerasan menghancurkan, melukai, menyakiti, menyiksa fisik dengan menggunakan tangan dan senjata lainnya baik senjata tajam maupun obat-obatan yang digunakan untuk menyakiti. Kekerasan seksual berupa kekerasan yang ditujukan untuk melukai alat seksual, di dalamnya termasuk pemaksaan dalam melakukan hubungan seksual. Kekerasan sosiologis merupakan kekerasan dengan menyerang harga diri yang termanivestasi dalam kegiatan merendahkan, mempermalukan sehingga menghancurkan motivasi. Kekerasan deprivasi merupakan kekerasan menelantarkan. Penelitian [3] mengutarakan bahwasanya perempuan sering sekali mengalami bentuk atau tindakan kekerasan, bahkan perempuan sering sekali dijadikan sebagai bentuk eksploitasi.

Pada 6 Maret 2020 siaran pers Catahu (Catatan Tahunan) Komnas Perempuan 2020 diterbitkan. Di dalamnya terdapat catatan kekerasan perempuan dan anak yang dicatat dalam tiga ranah. Ranah pertama adalah ranah privat/personal artinya pelaku adalah keluarga korban dan orang terdekat korban. kasus-kasus yang ditemukan yaitu kekerasan fisik, psikis, inses, seksual, dan ekonomi. Ranah kedua adalah ranah public/komunitas yaitu ranah yang di mana pelakunya bukan kerabat atau orang terdekat korban, orang yang tidak dikenal termasuk ke dalam ranah ini. Pada ranah ini tercatat beberapa kasus kekerasan seksual, yakni mencabuli, memerkosa, dan melecehkan. Ranah ketiga yaitu ranah negara artinya yang melakukan kekerasan adalah aparatur negara, kekerasan aparatur negara dapat berupa beban kapasitas tugas, juga bila terjadi peristiwa kekerasan, jika aparat negara mengetahuinya tapi membiarkannya dan tidak melakukan apa-apa maka hal tersebut termasuk ke dalam kategori ranah negara. Pada ranah negara kasus-kasus yang dilaporkan mencakup kebijakan diskriminatif dan administratif. Dari ketiga ranah tersebut, kekerasan pada ranah privat atau personal adalah yang paling banyak dilakukan — seperti tahuntahun sebelumnya yakni 75\%. Selain itu, Catuha Komnas Perempuan mencatat kenaikan kasus mengenai cybercrime meningkat pesat, Kasus siber terbanyak yaitu dalam bentuk intimidasi dan ancaman menyebarkan foto dan video porno korban[4]. Kenaikan kasus cybercrime yang pesat sejalan dengan penggunaan dunia digital yang kian hari kian masif. Kejahatan dunia maya merupakan hal yang harus ditanggapi dengan serius karena hari ini dunia digital bak kebutuhan pokok masyarakat.

Paragraf di atas menggambarkan bagaimana kekerasan yang terjadi terhadap perempuan menjadi permasalahan penting yang harus terus diperjuangkan, bagaimana pun perempuan memiliki hak yang sama seperti laki-laki yaitu hak untuk mendapatkan perlindungan sesuai dengan konstitusi yang berlaku di Indonesia. Negara ini memiliki sejarah panjang mengenai kekerasan terhadap perempuan, perempuan dijadikan objek seksual pemuas birahi dimulai sejak zaman penjajahan, bahkan kemerdekaan yang didapat tak lantas menghentikan kasus kekerasan pada perempuan. Beberapa bukti kekerasan terhadap perempun pun tertuang dalam karya sastra sebagai salah satu bentuk kritik masyarakat. Karya sastra dalam hal ini merupakan refleksi dari realitas, bahwa pengertian karya sastra sebagai refleksi realitas[5], artinya karya sastra bukan sekadar untuk melaporkan realitas itu sendiri tetapi juga merupakan realitas yang sudah bercampur dengan proses imajinatif pengarang yang di dalamnya termasuk realitas filsafat, sosial, dan psikologi. Peneliti [6] menyepakati terkait anggapan bahwa karya sastra tidak terlepas dari kreasi imajinatif seorang pengarang. Sebagaimanapun relevansinya dengan realitas, karya sastra tetap karya sastra yang makna realitas tersebut sudah tidak murni karena mengalami proses berpikir dan imajinasi pengarang. Dalam hal ini telah melewati proses penghayatan, pengamatan, perenungan, serta penilaian pengarang yang kemudian dibumbui oleh imajinasi. Maka dari itu, karya sastra disebut realitas yang imajinatif.

Salah satu bentuk kekerasan terhadap perempuan dalam karya sastra adalah pada novel Perempuan Kembang Jepun karya Lan Fang dan novel Kembang Jepun karya Remy Sylado. Novel yang memiliki kemiripan judul ini sama-sama diterbitkan oleh PT Gramedia Pustaka Utama dengan tahun yang berbeda. Kembang Jepun karya Remy Sylado lebih dulu terbit, yakni pada tahun 2004, tiga tahun setelahnya terbitlah novel Perempun Kembang Jepun karya Lan Fang. Uniknya, pada halaman terakhir novel Perempuan Kembang Jepun, Lan Fang mengaku telah 'menyontek' informasi untuk karyanya, salah satunya adalah novel Kembang Jepun karya Remy 
Sylado. Kedua Novel sama-sama mengungkapkan kritik sosial terhadap kekerasan perempuan terutama perihal seks pada tiga masa, yakni masa penjajahan Jepang dan Belanda, dan masa pasca kemerdekaan. Kedua novel ini menceritakan bagaimana kehidupan seorang Geisha dan perempuan Indonesia diperlakukan tidak manusisawi di ranah publik maupun domestik, di lingkungan sosial tempat di mana ia tinggal. Kedua novel ini sama-sama menunjukan betapa tidak adilnya perlakuan yang diterima perempuan, dari mulai bentuk kekerasan fisik, seksual, dan keterbatasan-keterbatasan hak yang sangat timpang dengan laki-laki.

Penelitian terhadap novel Kembang Jepun karya Remy Sylado dan novel Perempuan Kembang Jepun karya Lan Fang pernah dilakukan sebelumnya oleh beberapa peneliti baik dalam bentuk skripsi maupun jurnal. Penelitian terhadap novel Kembang Jepun karya Remy Sylado pernah dilakukan oleh [7]. Dalam penelitiannya Akbar membahas mengenai nilai moral yang terdapat dalam novel Kembang Jepun. Nilai moral di dalamnya meliputi hubungan manusia dengan Tuhan, hubungan manusia dengan dirinya sendiri, hubungan manusia dengan sesama manusia lainnya, hubungan keluarga yakni anak dan orang tua, serta hubungan dalam pekerjaan yakni bos dan pekerja, atasan dan bawahan.

Penelitian Terhadap novel Perempuan Kembang Jepun karya Lan Fang telah dikaji dalam [8] dimana ketidakadilan gender yang dititikberatkan pada penelitian tersebut adalah Ketidakadilan pada tokoh wanita yang berupa kekerasan terhadap perempuan, marginalisasi, dan subordinasi perempuan. Perempuan dan tindak kekerasan juga pernah diteliti oleh [9], dari penelitian tersebut tampak bahwa adat dan politik melahirkan tindak kekerasan yang bekasnya sulit dilupakan khususnya oleh tokoh perempuan. Dalam penelitian tersebut dapat terlihat bagaimana adat dan politik memberikan sebuah bentuk kekerasan yang harus dirasakan oleh pihak perempuan. Selain itu, upaya perjuangan yang dilakukan oleh tokoh perempuan sebagai subaltern tidaklah mudah karena harus berhadapan dengan upaya diskriminasi dan dominasi patriarki yang masih terus terjadi.

Dari penelitian sebelumnya, peneliti tidak menemukan penelitian yang menggabungkan kedua novel dalam satu instumen penelitian dengan pembahasan kekerasan terhadap tokoh perempuan dan mempertalikannya dengan kasus-kasus yang tercatat dalam Komnas Perempuan. Maka dari itu pada penelitian kali ini, peneliti akan menganalisis kedua novel sebagai suatu kajian sastra bandingan dengan menggunakan teori feminisme. Fokus dan tujuan umum pada penelitian ini ialah untuk memaparkan bentuk kekerasan terhadap tokoh perempuan dalam novel Perempuan Kembang Jepun Karya Lan Fang dan Novel Kembang Jepun Karya Remy Sylado serta mempertalikannya dengan fenomena kekerasan perempuan saat ini berdasarkan Catuha Komnas Perempuan 2020.

Penelitian kekerasan terhadap perempuan pada kedua novel tersebut menggunakan teori feminisme. Feminisme merupakan sebuah upaya gerakan yang memberikan perlawanan terhadap ketidaksetaraan antara laki-laki dan perempuan, gerakan ini memiliki tujuan untuk mencapai kesetaraan gender antara perempuan dan laki-laki. Gerakan feminisme bukanlah sebuah bentuk perlawanan yang dilakukan oleh perempuan terhadap laki-laki, bukan pula sebuah bentuk penentangan terhadap kehidupan sosial, dan bukan pula sebuah upaya perempuan untuk menghindari kodratnya melainkan ditujukan untuk menghentikan penindasan dalam bentuk apapun yang dialami oleh perempuan[2]. Seperti yang dikemukakan Ratna bahwa Feminisme hadir untuk menolak bentuk-bentuk perendahan terhadap kaum perempuan dalam berbagai ranah seperti politik, ekonomi, sosial, dan budaya[10]. Dari tujuan gerakan feminisme tersebut jelaslah kita tahu bahwa faktor penyebab adanya gerakan feminisme adalah karena banyak masyarakat yang menganggap rendah perempuan, anggapan tersebut menyebabkan terbatasnya ruang perempuan untuk berpikir dan menyampaikan pendapat.

Lahirnya kritik Feminisme didasari oleh ketidaksamarataan antara hak laki-laki dan hak perempuan. Ketidaksamaan hak tersebut yang membuat kesadaran perempuan terbuka untuk memperjuangkan haknya. Tujuan inti dari feminisme adalah mensejajarkan kedudukan perempuan dengan laki-laki dari berbagai aspek seperti pekerjaan, pendidikam, ekonomi, kehidupan sosial, dan kebebasan berpendapat. Banyak pakar yang membahas mengenai gerakan feminisme ini. Humm menjelaskan bahwa selanjutnya feminism menjadi gerakan yang 
terorganisisr untuk menuntut hak-hak perempuan[11]. Equal right's movement dan women's liberation movement merupakan upaya-upaya feminism dalam mencapai tujuannya. Equal right's movement merupakan gerakan persamaan hak antara perempuan dan laki-laki sehingga hak perempuan tidak lagi dibatasi. Women's liberation movement merupakan gerakan perempuan untuk membebaskan diri dari lingkungan domestik atau rumah tangga hal ini untuk membuktikan bahwa perempuan mampu berada di ranah public [12]. Melalui penjelasan tentang feminisme, peneliti menyimpulkan bahwasanya gerakan feminisme merupakan sebuah gerakan yang harus terus diperjuangkan, karna melalui gerakan inilah akan muncul sebuah upaya untuk menentang segala bentuk pembatasan dan kekerasan terhadap perempuan guna menyamaratakan hak antara laki-laki dan perempuan.

Menurut Deklarasi Penghapusan Kekerasan terhadap Perempuan yang terletak pada pasal 1, Segala macam jenis tindakan kekerasan yang di mana perempuan menjadi korban sehingga dapat menimbulkan penderitaan yang dialami secara langsung oleh perempuan. Bentuk kekerasan yang dialami oleh perempuan akan menimbulkan sebuah bentuk rasa sakit, ancaman, paksaan, juga pembebasan yang terbatas pada ranah publik maupun domestik. Pada pasal 1 tersebut merupakan sebuah penjelasan atas reaksi yang dialami perempuan ketika sudah mengalami bentuk kekerasan. Komnas perempuan menyatakan bahwa tindak kekerasan terhadap perempuan akan mengakibatkan kerugian termasuk penderiraan fisik, seksual maupun psikologis terhadap perempuan, baik perempuan dewasa atau anak perempuan dan remaja. Termasuk didalamnya ancaman, pemaksaan maupun secara sengaja meng-kungkung kebebasan perempuan [13]. Hal ini memberikan sebuah penjelasan bahwa kekerasan terhadap perempuan adalah segala bentuk kekerasan yang dialami oleh perempuan sehingga mengakibatkan rasa sakit karena adanya luka yang dialami oleh perempuan tersebut hal ini diakibatkan oleh adanya ancaman atau paksaan. Deklarasi yang dilakukan tersebut sejalan dengan pernyataan komnas perempuan yaitu segala macam bentuk kekerasan yang dialami oleh perempuan akan mengakibatkan kerugian bagi perempuan.

Selain menggunakan feminisme dalam penelitian ini, peneliti menggunakan ilmu sastra bandingan untuk melakukan penelitian karna ada dua novel yang akan dijadikan sebagai bahan penelitian untuk melihat bentuk kekerasan terhadap perempuan yang terdapat dalam karya sastra. Comparative literature atau la literature compare merupakan istilah lain dari sastra bandingan[14]. Peneliti [15] mengemukakan bahwa satu-satunya ilmu sastra yang tidak menghasilkan teori tersendiri adalah ilmu sastra bandingan. Peneliti [16] menjelaskan sastra bandingan merupakan daerah sastra yang memaparkan hubungan karya sastra satu dengan bidang sastra lainnya. Dari penjelasan mengenai sastra bandingan tersebut, peneliti menyimpulkan bahwasanya ilmu sastra bandingan sangat tepat untuk digunakan pada penelitian ini karena objek kajian yang akan diteliti merupakan dua novel yang berbeda. Melalui sastra bandingan pula peneliti akan membandingkan bentuk kekerasan apa saja yang terjadi pada kedua novel yang dijadikan sebagai objek penelitian, serta menemukan perbedaan bentuk kekerasan dalam kedua novel tersebut

\section{METODOLOGI PENELITIAN}

Penelitian ini menggunakan jenis penelitian kualitatif. Menurut penulis, penelitian kualitatif sangat relevan untuk digunakan dalam penelitian ini. Jenis penelitian kualitatif merupakan jenis penelitian yang temuannya tidak diperoleh melalui prosedur statistik, melainkan bentuk penelitian yang dijelaskan melalui bentuk kata-kata atau mendekripsikan lewat kata perkata dengan cara mengumpulkan data dari latar alami dengan memanfaatkan diri peneliti sebagai instrumen kunci. Menurut Bogdan dan Taylor yang dikutip oleh Lexy penelitian kualitatif merupakan langkah-langkah penelitian yang hasilnya berupa data deskriptif dari hal yang diamati [17]. Metode kualitatif bertujuan untuk menguraikan unsur-unsur yang membangun dalam novel yang dikaji, adapun yang dikaji oleh peneliti adalah tindak kekerasan pada tokoh perempuan. Data primer yang digunakan pada penelitian ini adalah adalah novel Kembang Jepun karya Remy 
Sylado dan novel Perempuan Kembang Jepun karya Lan Fang. Kedua buku yang dijadikan data primer ini sama-sama diterbitkan oleh PT. Gramedia Pustaka Utama. Novel Kembang Jepun karya Remy Sylado diterbitkan pada 2003 dengan tebal halaman 319 sedangkan novel Perempuan Kembang Jepun terbit pada Oktober 2006, novel ini memiliki tebal halaman 288. Penelitianpenelitian terdahulu, buku-buku pendukung, literature berupa jurnal, prosiding merupakan data sekunder dari penelitian ini.

Jabrohim dalam Suwartono berpendapat bahwa peneliti harus memiliki pemikiran yang kritis ketika melakukan penelitian. Teknik yang digunakan adalah membaca karya sastra dengan pemahaman mendalam dengan menerapkan strategi membaca berulang-ulang dan mencatat halhal penting yang berkaitan dengan objek yang diteliti. Teknik pengumpulan data yakni mengumpulkan, memilah, dan memilih data penelitian [18].

Teknik yang digunakan untuk penelitian ini yakni teknik kepustakaan dengan mengacu pada sumber-sumber yang bekaitan dengan objek penelitian seperti buku-buku, artikel, dan dokumendokumen lain yang berhubungan dengan objek penelitian, langkah-langkah yang dilakukan dalam menganalisis data adalah mengumpulkan data penelitian, kemudian penulis mengumpulkan informasi sebanyak mungkin dari hasil bacaan dan mereduksi data yang didapat sesuai dengan objek penelitian. Penulis melakukan pengamatan secara kontinu demi menghasilkan simpulan dari objek kajian yang diteliti.

\section{HASIL DAN PEMBAHASAN}

Novel Kembang Jepun karya Remy Sylado dan novel Perempuan Kembang Jepun karya Lan Fang menggambarkan kekerasan-kekerasan yang dialami perempuan. Kekerasan terhadap perempuan pada novel Perempuan Kembang Jepun karya Lan Fang dan novel Kembang Jepun karya Remy Sylado dapat dikaitkan dengan Catuha (Catatan Tahunan) Komnas Perempuan 2020 dengan maksud menggali jenis-jenis kekerasan yang dituangkan dalam kedua novel serta relevansinya dengan kejadian kekerasan terhadap perempuan di masa sekarang. Peneliti menemukan jenis-jenis kekerasan terhadap perempuan sesuai dengan Catuha Komnas Perempuan 2020, jenis-jenis kekerasan tersebut di bagi ke dalam ranah-ranah yang mengacu pada Catuha 2020 yaitu ranah privat/personal dan ranah publik/komunitas.

Pada ranah privat/personal kekerasan terhadap tokoh perempuan yang terdapat dalam novel Kembang Jepun karya Remy Sylado berupa kekerasan psikologis, kekerasan tersebut didapat dari ibu mertuanya sendiri yang tidak memberikan restu pada tokoh utama perempunKeke untuk menikah dengan Tjak Broto-anaknya karena ia seorang Geisha, hal itu terdapat dalam kutipan:

\section{"Sebetulnya, apa yang membuat kamu percaya pada perempuan seperti itu?"}

Ibu mertuanya sangat merendahkan profesi Keke sebagai geisha sehingga tidak pernah menyetujui cinta keduanya. Ibunya menganggap pilihan yang diambil Tjak Broto salah, keluarganya akan menjadi bahan gunjingan masyarakat karena pilihan anaknya tersebut. Pemikiran Ibu Tjak Broto mewakili pemikiran masyarakat pada saat itu terhadap sosok perempuan. Pekerjaan Geisha adalah pekerjaan tidak terhormat, sehingga Keke yang berprofesi sebagai Geisha diperlakukan dengan seenaknya cenderung kepada kekerasan psikologis.

Pada novel Perempuan Kembang Jepun karya Lan Fang kekerasan pada ranah privat/personal lebih ditonjolkan. Kekerasan pada ranah ini terjadi dalam berbagai bentuk seperti kekerasan fisik, kekerasan psikis, kekerasan seksual, dan kekerasan ekonomi. bentuk kekerasan terjadi hampir sepanjang jalan penceritaan. Hal itu dilakukan kepada tokoh utama perempuanSulis oleh suaminya - Sujono. Kekerasan fisik seperti dalam kutipan:

"dan seketika itu juga, tangannya melayang meninju mataku."

Tindak kekerasan ini dilakukan oleh Sujono kepada Sulis isteriya. Kehidupan rumah tangga mereka memang selalu di isi dengan amarah dan kekerasan. Sulis yang keras kepala dan selalu melakukan perlawanan harus berhadapan dengan Sujono yang tidak suka ditantang 
sehingga menyebabkan kekerasan demi kekerasan harus dilayangkan Sujono kepada Sulis untuk memberikan pelajaran. Awal hubungan pernikahan yang tidak berdasarkan cinta kedua belah pihak mengakibatkan kehidupan rumah tangga yang penuh tekanan dan menciptakan amarah di antara kedua pasangan suami isteri tersebut tidak berkesudahan.

Pada novel Perempuan Kembang Jepun kekerasan fisik juga dirasakan oleh Matsumi, isteri Sujono yang ia nikahi pasca meninggalkan Sulis yang berprofesi sebagai geisha. Cinta butanya kepada Sujono merupakan awal mula derita hidupnya. Menikah dengan Sujono seperti keputusan paling bodoh yang Matsumi ambil sepanjang hidupnya. Matsumi terjebak pada kehidupan rumah tangga yang tidak bahagia, ia juga harus menerima makian dari majikannya saat meninggalkan tempatnya bekerja.

Kubiarkan Hanada-san melampiaskan marah sepuas hatinya. Ia bukan saja menempelengi dan menjambakku, tapi juga menendang dan menginjak kepalaku. Setelah merasa cukup menghukumku, ia berdiri, memandangku dengan sorot mata yang tidak bisa kulerai maknanya. Dengan suara sedingin es yang bisa membuat gigi gemelutuk, ia berkata, "Pergilah... jangan pernah kembali lagi ke sini..." Setelah meludahi wajahku, ia pergi tanpa menoleh lagi kepadaku. Aku tersaruk sendiri di lantai, tapi aku tetap tidak menangis

Perlakuan Hanada-san kepada Matsumi menunjukkan kekuasaan laki-laki atas perempuan sehingga di sini Hanada-san bebas berlaku seenaknya kepada Matsumi yang selama ini sudah bekerja untuknya. Perlakuan ini menunjukkan bagaimana anggapan rendah terhadap perempuan berakibat pada perlakuan sewenang-wenang dari laki-laki, salah satunya bentuk kekerasan fisik seperti yang dialami tokoh Sulis dan Matsumi.

Kekerasan psikis, kerap kali dirasakan oleh Sulis, Sujono memang tidak terima atas pernikahannya dengan Sulis karena bukan keinginan dari hatinya. Hal itu terdapat dalam kutipan berikut:

\section{"ia selalu mencelaku karena ketika ia mengawiniku aku dalam keadaan mengandung muda"}

Tidak terima dengan keadaan yang mengharuskannya menikah dengan Sulis membuat Sujono berperilaku seenaknya sebagai pelampiasan. Kekerasan fisik belum cukup bagi Sujono untuk membalas sikap isterinya, maka Sujono berupaya sebisa mungkin untuk berkata-kata yang melukai hati atau psikis Sulis.

Masih belum cukup bagi Sujono, kekerasan secara ekonomi pun harus dialami Sulis, karena selama menjalani kehidupan berumah tangga, Sulis masih susah payah berjualan jamu untuk memenuhi kebutuhan sehari-harinya dengan Sujono. Hal ini terdapat dalam kutipan:

"lalu ia bangun dengan dada telanjang. Ia berjalan ke belakang. Dan tidak lama, kudengar bunyi pecahan botol-botol beruntun. Gigiku gemeretak menahan emosi. Aku bangkit menyusulnya ke belakang. Kulihat, botol-botol jamuku sudah pecah berserakan. Padahal dari botol-botol jamu itulah aku bisa membuat dandang masih mengepulkan asap nasi yang kutanak"

Perilaku tersebut masih karena penyebab yang sama, yaitu kekesalannya atas desakkan pernikahan Sulis kepada Sujono, membuat Sujono tidak pernah memberikan penghargaan sedikitpun kepada Sulis. Ia selalu melakukan apa saja termasuk hujatan-hujatan, kata-kata kasar untuk memberikan kepuasan atas kekesalannya.

"Aku mengawinimu hanya karena terpaksa. Kamu menjebakku..."

Tidak sampai disitu penderitaan Sulis, setelah semua derita yang dialami, ia juga harus menerima kekerasan seksual dari suaminya sendiri, seperti dalam kutipan:

"Belum tuntas rasa sakitku, belum sempurna kesadaranku, Mas Sujono bagaikan

banjir bandang, bagaikan harimau kelaparan, dating menerpa, menggulung, menindihiku! Ia mengangkat kedua pahaku tinggi-tinggi, melipatnya sampai ke atas 
dada, mendorong kepalaku sampai membentur dinding kamar. Aku merintih kesakitan. Air mataku membanjir, tapi ia tidak peduli. Ia menyetubuhiku sekali lagi dengan kasar dan lama sampai keringatnya bercucuran bagaikan curahan gerimis. Sampai akhirnya ia menghentikannya sendiri tanpa muncratan cairan hangat itu... Ia memerkosaku!!!”

Kekerasan demi kekerasan harus diterima perempuan karena dianggapnya perempuan adalah sosok yang rendah. Tidak bisa lebih tinggi dari laki-laki. Dengan anggapan tersebut, lakilaki merasa memiliki kuasa penuh sehingga bisa memperlakukan perempuan dengan semenamena, bahkan hal tersebut terjadi antara suami kepada isteri-ranah privat. Sulis sangat diperlakukan tidak pantas oleh suaminya sendiri.

Selanjutnya pada ranah publik/komunitas kekerasan terhadap tokoh perempuan yang terdapat dalam novel Kembang Jepun karya Remy Sylado banyak ditonjolkan, kekerasan tersebut digambarkan dalam bentuk kekerasan fisik, kekerasan psikologis, dan kekerasan seksual. Kekerasan fisik kerap kali dialami oleh tokoh utama perempuan, Keke. Seperti dalam ktuipankutipan:

"Kataro Takamura masuk pula ke ruangan itu dan mulailah saya menerima pukulan-pukulan hebat, seperti terhadap seorang musuh atau tawanan perang. Tangannya kuat, terasa bagai mengapak, menumbuk dan menebas, seakan seluruhnya mewakili perasaan, benci yang luar biasa. Olehnya, saya terhuyung-huyung. Bukan sekali saja, melainkan berkali-kali.terhuyung, jatuh, ditarik untuk bangunn kembali dan digebuk sehabisnya. Bagian kulit yang paling peka, seperti bibir, telah keluar darah karena cabik. Darah itu tertelan bersamakeringat yang bercampur dengan air mata..."

Perilaku Takamura kepada Keke dipicu oleh sikap Keke kepada seorang pelanggannya di Kembang Jepun yang dapat berakibat fatal dan menimbulkan kecurigaan-kecurigaan lain bagi si pelanggan-yang kemudian menjadi suami Keke. Karena perempuan-perempuan di tempat Kataro Takmura ini bukanlah orang Jepang sungguhan, melainkan bawaan kakak Keke dari Minahasa. Kepolosan Keke sebagi seorang Geisha baru di Shinju menjadikan ia sebagai bahan siksaan. Takamura sebagai bos atau majikan merasa berhak memperlakukan Keke dengan kasar. Takamura berkuasa penuh terhadap geisha-geisha yang ia pekerjaan, termasuk Keke.

"Dan langsung ditamparnya muka saya 'Kau harus mau!',

Pada kutipan ini diceritakan pemaksaan kepada Keke dari Hiroshi Masakuni, keadaan sedang tegang, karena Jepang megalami kekalahan, sehingga membuat seluruh orang Jepang yang menjajah Indonesia harus pergi ke Jepang meninggalkan Indonesia. Keke di paksa ikut ke Jepang, namun karena ia menolak dan terus mengeluh ingin kembali ke suaminya Tjak Broto, akhirnya Hiroshi Masakumi melakukan tindak kekerasan berupa tamparan dan ancaman kepada Keke. Kejadian ini menggambarkan bahwa setiap aturan yang dibuat laki-laki harus dituruti oleh perempuan. Perempuan dianggap sebagai mahluk inferior.

Kekerasan psikis dalam ranah publik/komunitas juga kerap dialami oleh Keke, kekerasan psikologis berupa penyerangan harga diri, penghancuran motivasi, perendahan, kegiatan yang mempermalukan dan sebagainya, seperti dalam kutipan:

"Mereka tidak peduli. Setelah saya diikat, Otto Walilangit berdiri dihadapan saya, memandang dengan sangat mengecilkan harkat"

Pandangan laki-laki pada saat itu kepada `perempuan memang selalu mengangap perempuan tidak berharkat. Laki-laki bisa menguasai apa saja, termasuk perempuan itu sendiri. Bentuk-bentuk pandangan seperti itu jelas saja akan melukai perempuan secara psikologis.

Kekerasan seksual pada ranah publik/komunitas dalam novel Kembang Jepun kepada tokoh utama perempuan digambarkan dengan sangat jelas, seperti dalam kutipan:

"Kobayashi meloncat, menerjang, dan menangkap saya dipintu yang tidak mungkin terbuka itu. Dipegangnya saya kencang-kencang, sampai saya merasa sakit., lalu mengerang. Oleh hal itu, ditamparnya saya, sehingga saya terhuyung dan jatuh tanpa 
daya. Dari lantai saya lihat ke atas. Ia seperti seekor singa yang siap mencabik-cabik domba yang tidak bersaya. Kemrungsung ia melepas-lepaskan seluruh kain yang membungkus tubuh saya, sampai tidak bersisa lagi, dan akhirnya ia sendiri melepaskan celannaya. Setelah itu ia melakukan apa yang ia pikir sebagai tugas perang mengalahkan musuh. Badebah! Anjing! Kunyuk! Dan seterusnya. Saya menangis..."

Bila penjajah Jepang mengeksploitasi laki-laki di Indonesia untuk kerja Rodi, maka para perempuan di Indonesia harus mengalami eksploitasi seksual yang dilakukan para penjajah Jepang di Indonesia. Para penjajah Jepang sangat memanfaatkan keberadaan perempuan Indonesia untuk kepuasan nafsunya. Seperti yang dilakukan Kobayashi, penjaga penjara. Kobayashi memanfaatkan keadaan Keke yang ingin bertemu suaminya yang di penjara, namun pertemuan itu harus di bayar dengan mahal nyatanya yang menyisakkan trauma mendalam bagi Keke.

Kekerasan terhadap perempuan dalam Novel Kembang Jepun, tidak hanya dilakukan oleh penjajah saja, tetapi juga oleh laki-laki dari Indonesia yang pemarah dan merasa memiliki kekuasaan di dalam dirinya, terutama atas perempuan-perempuan yang seakan di anggap sebagai alas kaki bagi mereka, seperti dalam kutipan:

"Dan lagi, akibatnya, ditamparnya berkali-kali muka saya, sampai saya tidak tahu lagi apakah sakitnya karena tangannya itu ataukah karena perilakunya. Ia terdiam sebentar, ia melihat ke kiri dan ke kanan. Matanya berhasil melihat sesuatu. Di pojok depan sana ada kain mirip taplak. Diambilnya kain itu lalu diikatya mulut saya. Dengan demikian saya tidak bisa membuka mulut dan berteriak. Tapi tali di kaki saya dilepasnya. Entah apa pula maunya. Ternyata setelah itu iaterik rok saya, sampai lepas, tinggal celana dalam. Dalam keadaan seperti ini, dengan kurang ajar tangannnya mengorek-ngorek apa yang diinginkannya. Di dorongnya saya ke atas, sampai saya berdiri dalam keadaan terikat di tiang penyangga, dan dengan begitu ia bisa mendorong tubuhnya ke tubuh saya yang tersandar di tiang penyangga itu. Terus terang, maksud saya dengan kata-kata ini, adalah ia berhasil memperkosa saya"

"setelah berminggu-minggu bergiliran memperkosa saya, tiba saat yang saya anggap aneh, sebab ternyata diantara mereka timbul rasa cemburu, yaitu rasa yang lebih berhak atas diri saya."

Begitulah Remy Sylado menggambarkan dengan jelas kekerasan-kekerasan seksual yang dialami perempuan pada novel Kembang Jepun. Pada novel Perempuan Kembang Jepun, Lan Fang juga menggambarkan kekerasan-kekerasan seskual yang dialami perempuan pada ranah publik/komunitas, kekerasan tersebut terdapat pada kutipan-kutipan berikut:

"Mereka menggagahi perempuan-perempuan di sana dengan penuh nafsu. Seorang perempuan harus digilir sepuluh sampai lima belas tentara Jepang karena jumlah tentara Jepang sangat banyak. Mereka tidak dibayar. Dan mereka juga tidak berani meminta bayaran. Bukannya uang mereka dapatkan, tapi mereka diludahi, dimaki, ditemplengi, dijambak, bahkan diinjak-injak. Tidak ada hari libur dan jam istirahat untuk mereka. Bahkan dalam keadaan haid pun, mereka tetap dipaksa menggangkangkan selangkangan. "dan seketika itu juga, tangannya melayang meninju mataku."

"pernah kudengar salah seorang diantar perempuan-perempuan itu mencoba menolak karena kencingnya sudah berdarah dan terasa nyeri. Sementara alat kelaminnya sudah berlendir dan menguarkan bau setumpukan bangkai tikus. Tubuhnya demam dan panas tinggi. Wajahnya sepucat mayat dan sudah tidak bisa lagi berjalan karena seluruh belulangnya seakan remuk. Ia sudah tidak mampu melayani pejantan-pejantan itu. "dan seketika itu juga, tangannya melayang meninju mataku."

Rasa berkuasa laki-laki kepada perempuan dilakukan tanpa pandang bulu. Tidak menilai perempuan itu sebagai isterinya atau orang tidak dikenal. Selagi laki-laki memiliki nafsu, maka 
perempuan mana saja bisa menjadi objek seksual laki-laki dan terserah laki-laki mau memperlakukan seperti apa setiap perempuan yang ada dihadapannya.

Novel Kembang Jepun karya Ramy Sylado memulai cerita kekerasan sejak Keke diantar kakanya untuk menjadi Geisha sampai menjelang akhir cerita. Berbagai bentuk kekerasan baik dalam ranah privat maupun publik selalu ditunjukkan Remy secara lugas. Walaupun cerita berakhir Happy ending. Tetapi seluruh jalan penceritaan teramat memilukkan bagi tokoh utama Keke sebagai perempuan yang direndahkan harkat dan martabatnya. Sama halnya dengan novel Perempuan Kembang Jepun karya Lan Fang, kekerasan kepada perempuan ditunjukkan dengan jelas bagaimana perlakuan seorang suami yang tidak manusiawi kepada istinya Sulis dan Matsumi.

Pada novel Kembang Jepun karya Remy Sylado bentuk-bentuk kekerasan pada tokoh utama perempuan terjadi pada dua ranah, yaitu ranah privat/personal dan ranah public/komunitas. Pada ranah publik, kekerasan yang terjadi adalah psikologis. Remy Sylado lebih banyak menunjukkan kekerasan dalam ranah publik yang mencakup kekerasan kekerasan fisik, kekerasan psikologis, dan kekerasan seksual. Berbeda halnya dengan gambaran kekerasan yang ditunjukkkan Lan Fang dalam Perempuan Kembang Jepun yang menonjolkan ranah privat/personal sebagai ruang kekerasan, kekerasan yang digambarkan yaitu kekerasan kekerasan fisik, kekerasan psikis, kekerasan seksual, dan kekerasan ekonomi.

Novel Kembang Jepun karya Ramy Sylado dan novel Perempuan Kembang Jepun menunjukkan bagaimana potret kekerasan terhadap perempuan di Indonesia sudah terjadi sejak ratusan tahun lalu. Anggapan bahwa perempuan lebih rendah dari berbagai aspek masih melekat hingga saat ini, hal itulah yang menyebabkan bentuk-bentuk kekerasan itu dapat terjadi di Indonesia. Bentuk-bentuk kekerasan terhadap perempuan yang digambarkan pada kutipan di atas yang diambil dari novel Kembang Jepun karya Ramy Sylado dan novel Perempuan Kembang Jepun merupakan bentuk-bentuk kekerasan yang bisa saja terjadi pada masa sekarang. Perlu adanya sebuah gerakan untuk terus menekan turunnya angka kekerasan terhadap perempuan. Komisi nasional anti kekerasan terhadap perempuan (Komnas Perempuan) merupakan sebuah lembaga yang sangat menolak adanya kekerasan terhadap perempuan. Melalui komnas perempuan banyak pasal-pasal yang dibuat guna melindungi hak-hak asasi atas perempuan.

Catatan-catatan dari komnas perempuan menunjukkan kepada kita bahwa kekerasan itu masih banyak terjadi hingga saat ini dan keadilan gender perlu diperjuangkan. Pemerintah indoneia telah berupaya dalam memberikan rasa aman terhadap warga negaranya, hal tersebut sudah diatur dalam hukum yang berlandaskan langsung kepada undang-undang yang berlaku. Pasal pasal yang berisi mengenai perlindungan atas hak asasi manusia pun sudah dibuat, hal ini guna memberikan rasa aman terhadap masyarakat. Menurut undang-undang nomor 39 tahun 1999 tentang Hak Asasi Manusia, hak yang harus dilindungi pemerintah terkait perlindungan hukum terhadap diri pribadi manusia atau tersangka yang menjalani proses pemeriksaan perkara pidana, antara lain: pertama hak perlindungan, (Pasal 29 ayat (1) UU No.39 Tahun 1999), kedua Hak Rasa Aman, (Pasal 30 UU No.39 Tahun 1999), ketiga Hak Bebas dari Penyiksaan, (Pasal 33 ayat (1) UU No.39 Tahun 1999)[19]. Pasal pertama tersebut merupakan sebuah upaya untuk memberikan perlindungan kepada korban ketika sedang melakukam pemerikasaa pidana. Dengan adanya pasal ini korban dapat melakukan sebuah upaya untuk melindungi dirinya. Pada pasal kedua dijelaskan bahwasanya setiap setiap warga negara memiliki hak rasa aman yang diatur dalam undang-undang. Dengan adanya pasal ini setiap warga negara berhak melakukan sebuah upaya perlindungan diri ketika sedang mengalami sebuah ancaman yang dihadapinya. Pada pasal ketiga setiap warga negara mempunyai hak untuk bebas dari penyiksaan yang terjadi terhadap dirinya. Setiap korban yang mengalami penyiksaan dapat berlindung dengan pasal tersebut unutk mendapatkan hak bebas dari penyiksaan tersebut.

Dengan adanya pasal-pasal yang membahas mengenai penindakan kekerasan terhadap perempuan guna memberikan rasa jera kepada pelaku kekeraan tersebut. Tingkat kekerasan terhadap perempuan yang masih terbilang tinggi menjadi sebuah alasan mengapa pasal-pasal tersebut harus di buat. Adanya sebuah bentuk diskriminasi terhadap perempuan merupakan sebuah pemicu atau faktor utama terjadinya bentuk kekerasan terhadap perempuan. 


\section{SIMPULAN}

Novel Perempuan Kembang Jepun karya Lan Fang dan novel Kembang Jepun karya Remy Sylado merupakan potret kekerasan terhadap perempuan yang digambarkan melalui karya sastra pada masa sebelum kemerdekaan dan pasca kemerdekaan. Melalui kedua novel tersebut dapat dilihat bagaimana kekeresan terhadap perempuan sudah terjadi sejak dulu sampai saat ini. Dalam kedua novel, perempuan sangat di anggap rendah oleh tokoh laki-laki, sehingga kekerasan pun banyak dilakukan melalui berbagai macam bentuk. Dalam Novel-novel ini Remy Sylado dan Lan Fang menyampaikan kritik sastra feminisme, dimana ketidakadilan gender sangat merugikan pihak perempuan. Kekerasan-kekerasan pada kedua novel ini terjadi di dalam dua ranah, yaitu ranah privat/personal dan ranah public/komunitas. Pada novel Kembang Jepun kekerasan lebih ditonjolkan di ranah publik berupa kekerasan fisik, psikologis, dan seksual. Sedangkan pada novel Perempuan Kembang Jepun kekerasan ditonjolkan dari ranah privat/personal yaitu dalam hubungan rumah tangga yang dijalani pemeran utama berupa kekerasan fisik, psikis, seksual, dan ekonomi. Dengan adanya sebuah lembaga komnas perempuan yang berfokus pada anti kekerasan terhadap perempuan dan didukung oleh peranan masyarakat semoga dapat menurunkan angka kekerasan terhadap perempuan khususnya di Indonesia

\section{REFERENCES}

[1] Admin, "siaran pers komnas perempuan 75 tahun hari kemerdekaan republik Indonesia," siaran pres \& pernyataan sikap. https://komnasperempuan.go.id/siaran-pers-pernyataansikap-detail/siaran-pers-komnas-perempuan-75-tahun-hari-kemerde.

[2] M. D. Solo, "Tindak Kekerasan Dalam Novel Perempuan Kembang Jepun Karya Lan Fang," 2010.

[3] R. I. Rahmawati, "Pemikiran Nawal El-Saadawi Dalam Karya Novel 'Memoar Seorang Dokter Perempuan' (Studi Analisis Gender Mansour Fakih)," Yogyakarta, 2018.

[4] Admin, "Catatan Tahunan Kekerasan terhadap Perempuan 2019 Kekerasan Meningkat: Kebijakan Penghapusan Kekerasan Seksual untuk Membangun Ruang Aman Bagi Perempuan dan Anak Perempuan," Komnas Perempuan, 2020. https://komnasperempuan.go.id/pengumuman-detail/siaran-pers-dan-lembar-faktakomnas-perempuan-cata.

[5] M. Ma'rifatun and M. Widayati, "Majas Dalam NOvel Ketika Cinta Bertasbih 2 Karya Habiburrahman El Shirazy (Kajian Stilistika dan Relevansinya sebagai Bahan Ajar Bahasa Indonesia)," Stilistika Kaji. Bahasa, Sastra dan Pembahasannya, vol. 5, no. 1, 2019, doi: https://doi.org/10.32585/.v5i1.611.

[6] N. Yanti, S. Suhartono, and R. Kurniawan, "Penguasaan Materi Pembelajaran Kerampilan Berbahasa Indonesia Mahasiswa S1 Program Studi Pendidikan Bahasa dan Sastra Indonesia FKIP Universitas Bengkulu," J. Ilm. Korpus, vol. 2, no. 1, 2018, doi: https://doi.org/10.33369/jik.v2i1.5559.

[7] R. Remmysilado, "Analisis Sosiologi Sastra Novel Kembang Jepun Karya Remy Sylado," J. ilmu budaya, vol. 1, no. 1, pp. 28-39, 2011, [Online]. Available: https://media.neliti.com/media/publications/240577-analisis-sosiologi-sastra-dalamnovel-be-e15ad4cb.pdf.

[8] S. Suwarti, "Ketidakadilan Jender Dalam Novel Perempuan Kembang Jepun Karya Lan Fang: Kajian Sastra Feminis," Surakarta, 2009.

[9] N. D. Haryanti, "Jejak Kekerasan Pada Novel Tarian Bumi Karya Oka Rusmini," J. Indones. Lang. Educ. Lit., vol. 3, no. 1, p. 150, 2017, doi: 10.24235/ileal.v3i1.1379.

[10] N. K. Ratna, Teori, Metode, dan Teknik Penelitian Sastra. 2001.

[11] C. Buana, "Sejarah, teori dan Aplikasi Kritik Sastra Feminis," Bul. Al-Turas, vol. 15, no. 3, 2009, doi: https://doi.org/10.15408/bat.v15i3.4270. 
[12] S. M. Pradita, "Sejarah Pergerakan Perempuan Indonesia Abad $19-20$ : Tinjauan Historis Peran Perempuan dalam Pendidikan Bangsa," Chronol. J. Hist. Educ., vol. 2, no. 2, pp. 12-27, 2020, doi: https://doi.org/10.22236/jhe.v2i2.6060.

[13] A. Surtinah, "Studi Tentang Efektifitas Hukum Penanganan Kasus Kekerasan Terhadap Perempuan Di Pelayanan Terpadu Perempuan dan Anak Surakarta ( PTPAS )," Surakarta, 2017.

[14] N. H. Hasan, "Cerita Rakyat 'Buaya Learissa Kayeli' Dan 'Buaya Tembaga, Pakuela, Sang Penguasa Baguala,"” ARBITRER J. Pendidik. Bhs. dan Sastra Indones., vol. 1, no. 2, pp. 109-124, 2019, doi: 10.30598/arbitrervol2no1 hlm109-124.

[15] F. Juliani, "Perjuangan Perempuan dalam Novel Para Pawestri Pejuang Karya Suparto Brata dan Novel God's Call Girl Karya Carla Van Raay (Kajian Sastra Bandingan)," Ling. Fr. Bahasa, Sastra, dan Pengajarannya, vol. 2, no. 2, p. 1, 2018, doi: 10.30651/lf.v2i2.1735.

[16] V. N. Santosa, "Pengembangan Buku Ajar Penelitian Pembelajaran Bahasa dan Sastra Indonesia Berbasis Penguatan Konseptual," JBT J. Basataka, vol. 3, no. 2, pp. 66-72, 2020, doi: https://doi.org/10.36277/basataka.v3i2.88.

[17] J. L. Moleong, Metodologi Penelitian Kualitatif. 2002.

[18] L. J. Moleong, Metodologi Penelitian Kualitatif, cet. 2018.

[19] A. S. Mujiyono, "Analisis Perlindungan Hukum Hak Tersangka dan Potensi Pelanggarannya Pada Penyidikan Perkara Pidana," Surakarta, 2009. 